Analisa Yuridis Peran Kantor Wilayah..........(Taufik)

\title{
ANALISA YURIDIS PERAN KANTOR WILAYAH KEMENTERIAN HUKUM DAN HAM DALAM PENGELOLAAN DAN PELAYANAN DATABASE PERATURAN PERUNDANG-UNDANGAN DI DAERAH
}

\section{(Juridical Analysis on Roles of Regional Offices of The Ministry of Law And Human Rights in Management and Administration of Database of Regional Laws and Regulations)}

\author{
Taufik H. Simatupang \\ Pusat Pengkajian dan Pengembangan Kebijakan \\ Badan Penelitian dan Pengembangan Hukum dan Hak Asasi Manusia \\ Kementerian Hukum dan Hak Asasi Manusia Republik Indonesia \\ JI. HR Rasuna Said Kavling 4 - 5, Jakarta Selatan 12940 \\ Telepon (021) 2525015 Faksimili (021) 2526438 \\ taufikhsimatupang73@gmail.com
}

Tulisan Diterima: 28 Agustus 2017; Direvisi: 6 Maret 2018;

Disetujui Diterbitkan:19 Maret 2018

DOI: http://dx.doi.org/10.30641/kebiiakan.2018.V12.1-19

\begin{abstract}
Abstrak
Keberhasilan reformasi dan revitalisasi hukum, sangat ditentukan berbagai aspek.Salah satunya penataan regulasi yang berkualitas, tidak tumpang tindih, ramah investasi dan menjunjung tinggi penghormatan terhadap hak asasi manusia, baik di tingkat Pusat maupun Daerah.Dalam pelaksanaan peran Kantor Wilayah Kementerian Hukum dan Hak Asasi Manusia sebagai pembina dan koordinator harmonisasi dan sinkronisasi rancangan peraturan perundang-undangan di daerah, maka kegiatan inventarisasi produk hukum daerah menjadipenting sebagai dasar mengembangkan pengelolaan dan pelayanan database produk hukum daerah. Dengan tertatanya database diharapkan dapat meningkatkan peran Kantor Wilayah dalam pembangunan sistem hukum nasional. Permasalahan penelitian adalah bagaimana pengelolaan dan pelayanan database peraturan perundang-undangan di daerah yang sudah dilaksanakan selama ini, peran Kantor Wilayah Kementerian Hukum dan Hak Asasi Manusia dan faktorfaktor penghambat. Dari hasil penelitian dapat disimpulkan bahwa peran Kantor Wilayah Kementerian Hukum dan Hak Asasi Manusia dalam pengelolaan dan pelayanan database peraturan perundangundangan di daerah belum maksimal. Oleh karena itu perlu perubahan atas Peraturan Menteri Hukum dan Hak Asasi Manusia Nomor 28 Tahun 2014 Tentang Organisasi dan Tata Kerja dengan menambah kewenangan melakukan analisis setiap produk Peraturan Daerah yang dikeluarkan Pemerintah Daerah. Perlu peningkatan kuantitas dan kualitas Sumber Daya Manusia yang memiliki kompetensi di bidang informasi dan teknologi melalui kegiatan pelatihan dan bimbingan teknis, dukungan anggaran dan sarana prasarana yang memadai.
\end{abstract}

Kata Kunci: Analisa Yuridis, Peran Kantor Wilayah, Jaringan Data dan Informasi Hukum, Pengelolaan dan Pelayanan Database, Produk Hukum Daerah

\begin{abstract}
Successful legal reform and revitalization are significantly determined by different aspects. One of the aspects is the administration of quality regulations, not overlapping, investment-friendly and upholding and respecting the human rights, both at the Central and Regional levels. In performing the roles of the Regional Office of the Ministry of Law and Human Rights as the fosterer and coordinator of the harmonization and synchronization of regional laws and regulations drafts, the activity of preparing the regional legal products inventory becomes important as the inventory will serve as the basis for the development, administration and management of the database of regional legal products. By the good administration of the database the roles of Regional Office of in the development of national legal system is expected to improve. The subject of this research is the administration and management of the
\end{abstract}


database of regional laws and regulations that had been implemented all this time, roles of the Regional Office of the Ministry of Law and Human Rights as well as the impending factors. From the result of the research, it may be concluded that the roles of Regional Office of the Ministry of Law and Human Rights in the management and administration of database of regional laws and regulations have not been optimal. Therefore, amendment is required to the Regulation of the Minister of Law and Human Rights No. 28 of 2014 regarding Organization and Work Procedures by additional power to conduct analysis against any products of Regional Regulations issued by the Regional Government. It is necessary to improve the quantity and quality of competent human resources in information and technology through Technical Training and Guideline, supporting budget and adequate facilities and infrastructure.

Keywords: Juridical Analysis, Roles of Regional Office, Legal Data and Information Network, Management and Administration of Database, Regional Legal Products

\section{PENDAHULUAN}

\section{Latar Belakang}

Kondisi saat ini di bidang pembangunan hukum dan aparatur ${ }^{1}$ dalam era reformasi merupakan upaya perwujudan sistem hukum nasional yang mencakup beberapa hal. Pertama pembangunan substansi hukum, baik hukum tertulis maupun hukum tidak tertulis telah mempunyai mekanisme untuk membentuk hukum nasional yang lebih baik sesuai dengan kebutuhan pembangunan dan aspirasi masyarakat, yaitu berdasarkan Undang-undang Nomor 12 Tahun 2011 Tentang Pembentukan Peraturan Perundang-undangan. Dengan ditetapkannya undang-undang tersebut, proses pembentukan peraturan perundang-undangan dapat diwujudkan dengan cara dan metode yang pasti, baku, dan standar yang mengikat semua lembaga yang berwenang untuk membuat peraturan perundang-undangan serta meningkatkan koordinasi dan kelancaran proses pembentukan peraturan perundangundangan. Kedua hingga saat ini, pelaksanaan program pembangunan aparatur Negara masih menghadapi berbagai permasalahan dalam penyelenggaraan Negara dan pemerintahan. Permasalahan tersebut, antara lain masih terjadinya praktik-praktik penyalahgunaan kewenangan dalam bentuk KKN danbelum terwujudnya harapan masyarakat atas pelayanan yang cepat,murah,manusiawi, dan berkualitas. Upaya yang sungguh-sungguh untukmemberantas KKN dan meningkatkan kualitas pelayanan publik sebenarnya telah banyak dilakukan. Walaupun demikian, hasil yang dicapai belum cukup menggembirakan. Kelembagaan pemerintah, baik dipusat maupun di daerah, masih belum terlihat efektif dalam membantu pelaksanaan tugas dan sistem manajemen pemerintahan juga belum

\footnotetext{
${ }^{1}$ Undang-undang Nomor 17 Tahun 2007 Tentang Rencana Pembangunan Jangka Panjang Nasional (RPJPN) Tahun 2005 - 2025.
}

efisiendalam menghasilkan dan menggunakan sumber-sumber daya. Upaya-upayauntuk meningkatkan profesionalisme birokrasi masih belum sepenuhnya dapat teratasi mengingat keterbatasan dana pemerintah.

Tantangan ke depan di bidang pembangunan hukum dan aparatur di dalam mewujudkan sistem hukum nasional yangmantap adalah mewujudkan sistem hukum nasional yang menjamin tegaknya supremasi hukum dan hak asasi manusia berdasarkan keadilan dan kebenaran. Saat ini birokrasi belum mengalami perubahan mendasar.Banyak permasalahan belum terselesaikan. Permasalahan itu makin meningkat kompleksitasnya dengan desentralisasi, demokratisasi, globalisasi, dan revolusi teknologi informasi. Proses demokratisasi yang dijalankan telah membuat rakyat makin sadar akan hak dan tanggung jawabnya. Untuk itu, partisipasi masyarakat dalam penyelenggaraan negara termasuk dalam pengawasan terhadap birokrasi perlu terus dibangun dalam rangka mewujudkan tata pemerintahan yang baik. Tingkat partisipasi masyarakat yang rendah akan membuat aparatur negara tidak dapat menghasilkan pembangunan yang tepat. Kesiapan aparatur negara dalam mengantisipasi proses demokratisasi perlu dicermati agar mampumemberikan pelayanan yang dapat memenuhi aspek transparansi, akuntabilitas, dan kualitas yang prima dari kinerja organisasi publik. Globalisasi juga membawa perubahan yang mendasar pada sistem danmekanisme pemerintahan. Revolusi teknologi dan informasi akan mempengaruhi terjadinya perubahan manajemen penyelenggaraan Negara dan pemerintahan. Pemanfaatan teknologi informasi dalam bentuk e-government, e-procurement, e-business dan pelayanan database peraturan perundangundangan, selain akan menghasilkan pelayanan publik yang lebih cepat, lebih baik, dan lebih murah, juga akan meningkatkan prinsip-prinsip tata pemerintahan yang baik. 
Arah, tahapan dan prioritas pembangunan jangka panjang tahun 20052025 adalah mewujudkan bangsa yang maju, mandiri, dan adil sebagai landasan bagi tahap pembangunan berikutnya menuju masyarakat adil dan makmur dalam Negara Kesatuan Republik Indonesia berdasarkan Pancasila dan Undang-Undang Dasar Negara Republik Indonesia Tahun 1945. Sebagai ukuran tercapainya Indonesia yang maju, mandiri, dan adil, pembangunan nasional dalam 20 tahun mendatang diarahkan pada pencapaian sasaran-sasaran pokok, salah satunya adalah terwujudnya Indonesia yang demokratis, berlandaskan hukum dan berkeadilan ditunjukkan oleh hal-hal berikut:

1. Terciptanya supremasi hukum dan penegakan hak-hak asasi manusia yang bersumber pada Pancasila dan UndangUndang Dasar Negara Republik Indonesia Tahun 1945 serta tertatanya sistem hukum nasional yang mencerminkan kebenaran, keadilan, akomodatif, dan aspiratif. Terciptanya penegakan hukum tanpa memandang kedudukan, pangkat, dan jabatan seseorang demi supremasi hukum dan terciptanya penghormatan pada hakhak asasi manusia.

2. Menciptakan landasan konstitusional untuk memperkuat kelembagaan demokrasi.

3. Memperkuat peran masyarakat sipil dan partai politik dalam kehidupan politik.

4. Memantapkan pelembagaan nilai-nilai demokrasi yang menitikberatkan pada prinsip-prinsip toleransi, non-diskriminasi, dan kemitraan.

5. Terwujudnya konsolidasi demokrasi pada berbagai aspek kehidupan politik yang dapat diukur dengan adanya pemerintah yang berdasarkan hukum, birokrasi yang profesional dan netral, masyarakat sipil, masyarakat politik dan masyarakat ekonomi yang mandiri, serta adanya kemandirian nasional.

Rencana Pembangunan Jangka Panjang Nasional (RPJPN) 2005-2025 di bidang pembangunan hukum dan aparatur ini juga sejalan dengan visi Kabinet Pemerintahan Joko Widodo dan Jusuf Kalla yaitu terwujudnya Indonesia yang berdaulat, mandiri dan berkepribadian berlandaskan gotong royong, dengan 7 (tujuh) misi, yaitu:

1. Mewujudkan keamanan nasional yang mampu menjaga kedaulatan wilayah, menopang kemandirian ekonomi dengan mengamankan sumberdaya maritim, dan mencerminkan kepribadian Indonesia sebagai negara kepulauan.
2. Mewujudkan masyarakat maju, berkesinambungan dan demokratis berlandaskan negara hukum.

3. Mewujudkan politik luar negeri bebas-aktif dan memperkuat jati diri sebagai negara maritim.

4. Mewujudkan kualitas hidup manusia Indonesia yang tinggi, maju dan sejahtera.

5. Mewujudkan bangsa yang berdaya saing.

6. Mewujudkan Indonesia menjadi negara maritim yang mandiri, maju, kuat dan berbasiskan kepentingan nasional.

7. Mewujudkan masyarakat yang berkepribadian dalam kebudayaan.

Untuk menunjukkan jalan prioritas dalam jalan perubahan menuju Indonesia yang berdaulat secara politik, mandiri dalam bidang ekonomi dan berkepribadian dalam kebudayaan, maka dirumuskan 9 (sembilan) agenda prioritas yang disebut Nawa Cita, yaitu : 1. Menghadirkan kembali negara untuk melindungi segenap bangsa dan memberikan rasa aman pada seluruh warga negara, melalui pelaksanakan politik luar negeri bebas aktif, melindungi hak dan keselamatan warga negara Indonesia di luar negeri khususnya pekerja migran, kedaulatan maritim, meningkatkan anggaran pertahanan 1,5 persen dari GDP dalam 5 tahun ke depan, mengembangkan industri pertahanan nasional, menjamin rasa aman warga negara dengan membangun Polri yang profesional.

2. Membuat pemerintahan tidak absen dengan membangun tata kelola pemerintahan yang bersih, efektif, demokratis, dan terpercaya, pemulihan kepercayaan publik melalui reformasi sistem kepartaian, pemilu dan lembaga perwakilan, meningkatkan peranan dan keterwakilan perempuan dalam politik dan pembangunan, memperkuat kantor kepresidenan untuk menjalankan tugastugas kepresidenan secara lebih efektif, membangun transparansi tata kelola pemerintahan, menjalankan reformasi birokrasi, dan membuka partisipasi publik.

3. Membangun Indonesia dari pinggiran dengan memperkuat daerah-daerah dan desa dalam kerangka negara kesatuan, melalui desentralisasi asimetris, pemerataan pembangunan antar wilayah terutama desa, kawasan timur Indonesia dan kawasan perbatasan, penataan daerah otonom baru untuk kesejahteraan rakyat, dan implementasi Undang-undang desa.

4. Menolak negara lemah dengan melakukan reformasi sistem dan penegakan hukum yang bebas korupsi, bermartabat dan 
terpercaya, membangun politik legislasi yang kuat, pemberantasan korupsi, penegakan HAM, memperkuat KPK, memberantas mafia peradilan, pemberantasan tindakan penebangan liar, perikanan liar dan penambangan liar, pemberantasan narkoba dan psikotropika, pemberantasan tindak kejahatan perbankan dan pencucian uang, menjamin kepastian hukum dan pemilikan tanah, melindungai anak, perempuan dan kelompok masyarakat marjinal, menghormati HAM dan pnyelesaian secara berkeadilan terhadap kasus-kasus pelanggaran HAM pada masa lalu, dan membangun budaya hukum.

5. Meningkatkan kualitas hidup manusia Indonesia, dengan program "Indonesia Pintar" melalui wajib belajar 12 tahun bebas pungutan, program kartu "Indonesia Sehat" melalui layanan kesehatan masyarakat, progam "Indonesia Kerja" dan "Indonesia Sejahtera" melalui reformasi agraria 9 juta hektar untuk rakyat tani dan buruh tani, rumah susun bersubsidi dan jaminan sosial.

6. Meningkatkan produktivitas rakyat dan daya saing di pasar internasional sehingga bangsa Indonesia bisa maju dan bangkit bersama bangsa-bangsa Asia lainnya, melalui pembangunan infrastruktur jalan baru sepanjang sekurang-kurangnnya 2.000 kilometer, membangun sekurang-kurangnya 10 pelabuhan baru dan merenovasi yang lama, membangun sekurang-kurangnya 10 bandara baru dan merenovasi yang lama, membangun sekurang-kurangnya 10 kawasan industri baru berikut pengembangan untuk hunian buruhnya, membangun sekurang-kurangnya 5.000 pasar tradisional di seluruh Indonesia dan memodernisasikan pasar tradisional yang telah ada, menciptakan layanan satu atap untuk investasi, efisiensi perijinan bisnis menjadi maksimal 15 hari, dan membangun sejumlah Science and Teknopark di kawasan Politeknik dan SMK-SMK dengan prasarana dan sarana teknologi terkini.

7. Mewujudkan kemandirian ekonomi dengan menggerakkan sektor-sektor strategis ekonomi domestik, melalui pembangunan kedaulatan pangan, mewujudkan kedaulatan energi, mewujudkan kedaulatan keuangan, mendirikan Bank Petani/Nelayan dan UMKM termasuk gudang dengan fasilitas pengolahan pasca panen ditiap sentra produksi tani/nelayan, dan, mewujudkan penguatan teknologi penciptaan sistem inovasi nasional.
8. Melakukan revolusi karakter bangsa, melalui pembangunan pendidikan kewarganegaraan, mengevaluasi model penyeragaman dalam sistem pendidikan nasional, jaminan hidup yang memadai bagi para guru terutama bagi guru yang ditugaskan di daerah terpencil, memperbesar akses warga miskin untuk mendapatkan pendidikan tinggi, memprioritaskan pembiayaan penelitian yang menunjang iptek.

9. Memperteguh Kebhinekaan dan memperkuat restorasi sosial Indonesia, melalui penguatan pendidikan Kebhinekaan dan menciptakan ruang-ruang dialog antar warga, restorasi sosial untuk mengembalikan ruh kerukunan antar warga, membangun kembali gotong-royong sebagai modal sosial melalui rekonstruksi sosial, mengembangkan insentif khusus untuk memperkenalkan dan mengangkat kebudayaan lokal, dan meningkatkan proses pertukaran budaya untuk membangun kemajemukan sebagai kekuatan budaya.

Dalam rangka mendorong revitalisasi dan reformasi hukum, dua program prioritas Nawacita yang terkait dengan pembangunan hukum dan aparatur dapat dilihat dalam Nawacita 1 yaitu menghadirkan kembali negara untuk melindungi segenap bangsa dan memberikan rasa aman pada seluruh warga negara. Kemudian Nawacita 4 yaitu menolak negara lemah dengan melakukan reformasi sistem dan penegakan hukum yang bebas korupsi, bermartabat dan terpercaya. Dari kedua program prioritas Nawacita ini diharapkan dapat mendorong pemulihan kepercayaan publik sekaligus terciptanya keadilan dan kepastian hukum.

Tingkat keberhasilan revitalisasi hukum, dalam kerangka mengembalikan kepercayaan publik $^{2}$, terciptanya keadilan dan kepastian hukum, sangat ditentukan berbagai aspek, tiga diantaranya adalah: Pertama penataan regulasi

\footnotetext{
${ }^{2}$ Kepercayaan publik tentunya hanya bisa dikembalikan apabila kualitas pelayanan dapat diperbaiki dan ditingkatkan sesuai dengan prinsip-prinsip pelayanan publik sebagaimana diatur dalam Pasal 4, yang beorientasi kepada kepentingan umum, kepastian hukum, kesamaan hak, keseimbangan hak dan kewajiban, keprofesionalan, partisipatif, persamaan perlakuan/tidak diskriminatif, keterbukaan, akuntabilitas, fasilitas dan perlakuan khusus bagi kelompok rentan ketepatan waktu dan kecepatan, kemudahan, dan keterjangkauan. Lihat juga prinsip-prinsip pemerintahan yang baik sebagaimana diatur dalam Peraturan Pemerintah Nomor 101 Tahun 2000, yang meliputi prinsip-prinsip profesionalitas, akuntabilitas, transparansi, pelayanan prima, demokrasi, efisiensi, efektifitas, supremasi hukum dan dapat diterima oleh seluruh masyarakat.
} 
yang bertujuan menghasilkan regulasi berkualitas, tidak tumpang tindih antar peraturan perundang-undangan, baik vertikal maupun horizontal, ramah terhadap investasi dan menjunjung tinggi penghormatan terhadap HAM. Kedua pembenahan kelembagaan yang bertujuan mendorong terciptanya lembaga penegak hukum yang kuat, profesional dan bermoral serta berintegritas. Ketiga pembangunan budaya hukum yang bertujuan mencptakan budaya hukum masyarakat yang kuat.

Untuk mewujudkan regulasi berkualitas, tidak tumpang tindih, ramah investasi dan menjunjung tinggi nilai-nilai penghormatan terhadap HAM, sangat dibutuhkan data yang terkompilasi secara elektronik, terintegrasi dan dapat diakses setiap waktu dalam satau database. Pertentangan antar peraturan perundang-undangan menjadi salah satu masalah hukum di Indonesia yang tak kunjung selesai. Banyak produk hukum yang dihasilkan DPR maupun pemerintah tidak sinkron dengan peraturan lain, baik yang setara maupun lebih tinggi kedudukannya. Kualitas harmonisasi dan sinkronisasi rancangan peraturan perundangundangan jadi perhatian utama banyak pemerhati hukum. Bahkan tidak jarang, peraturan organik tidak merujuk sama sekali pada peraturan yang lebih tinggi. Berbagai kalangan menilai, hal ini disebabkan proses harmonisasi dan sinkronisasi rancangan peraturan perundang-undangan belum dilakukan secara maksimal. Akibatnya, tidak sedikit aturan baru yang bertentangan dengan aturan yang berlaku lebih awal. Disisi lain, belum tertata dan terintegrasinya database peraturan perundang-undangan juga menjadi salah satu penyebab.

Menurut Direktur Analisa Peraturan Perundang-undangan Bappenas Arif Christiono Soebroto $^{3}$, perlu ada pengaturan database hukum nasional, karena tidak hanya satu lembaga yang berwenang menyebarkan informasi terkait peraturan perundangundangan. Peraturan setingkat Undang-undang dan Peraturan Pemerintah bisa disebarkan oleh Sekretariat Negara, Kementerian Hukum dan HAM (Kemenkumham) dan kementerian pemrakarsa, bahkan untuk Peraturan Daerah (Perda) Kementerian Dalam Negeri (Kemendagri) juga ikut menyebarkan. Data

\footnotetext{
${ }^{3}$ http://www.hukumonline.com/berita/baca/lt4d0989a80b9a $\mathrm{f} /$ minimnya-idatabasei-peraturanpersulit-harmonisasi-

hukum Minimnya Database Peraturan Persulit Harmonisasi Hukum Penyelenggaraan sistem informasi peraturan perundang-undangan masih sektoral dan tidak lengkap. (Dilihat Pada Tanggal 5 Januari 2017)
}

sampai dengan tahun $2016^{4}$ menunjukkan bahwa Perda/Perkada Kabupaten/Kota yang dicabut/direvisi oleh Menteri Dalam Negeri adalah terjadi di semua provinsi di seluruh Indonesia, yang paling banyak tercatat di Provinsi Jawa Barat 133 Perda/Perkada Kab/Kota dan paling sedikit di Provinsi DKI Jakarta 2 Perda/Perkada Kab/Kota. Fakta ini patut diduga disebabkan belum tertatanya dengan baik peraturan perundang-undangan di daerah, karena database peraturan perundangundangan pada dasarnya tidak saja persoalan mengkompilasi secara elektronik tetapi juga termasuk harmonisasi dan sikronisasinya. Di sisi yang lain antara database Badan Pembinaan Hukum Nasional BPHN)dan Direktorat Jenderal Peraturan Perundangundangan (Ditjen PP) maupun Kemendagri memang berbeda. Namun demikian perlu digagas website yang saling terintegrasi. Fakta lain adanya dugaan selama ini dalam penghimpunan database peraturan perundangundangan di daerah, BPHN langsung berkoordinasi dengan Pihak Pemerintah Daerah (Pemda) tanpa melalui Kantor Wilayah (Kanwil) Kemenkumham.

Dalam Pasal 225 Peraturan Menteri Hukum dan HAM Nomor 29 Tahun 2015 Tentang Organisasi dan Tata Kerja Kemenkumham disebutkan bahwa Direktorat Fasilitasi Perancangan Peraturan Daerah dan Pembinaan Perancang Peraturan Perundangundangan mempunyai tugas melaksanakan penyiapan perumusan dan pelaksanaan kebijakan, pemberian bimbingan teknis dan supervisi, serta pelaksanaan pemantauan, evaluasi dan pelaporan di bidang fasilitasi perancangan peraturan daerah dan pembinaan perancang peraturan perundang-undangan sesuai dengan kebijakan teknis yang ditetapkan oleh Direktur Jenderal Peraturan Perundangundangan. Bidang fasilitasi perancangan peraturan daerah melaksanakan:

1. Pembinaan perancangan Perda

a. Konsultasi pembentukan Perda;

b. Supervisi perancangan Perda;
(implementasi
Kepmen
No.M.HH-

01.PP.05.01 Tahun 2016 Tentang

Pedoman Fasilitasi Pembentukan Perda

c. Bimbingan Teknis Perancangan Perda.

(Implementasi Kepmen No.MHH03.PP.01.02 Tahun 2016 Tentang Pedoman Bimbingan Teknis Penyusunan Perda)

\footnotetext{
${ }^{4}$ http://www.kemendagri.go.id/media/filemanager/2016/06/ 21/b/a/batal_perda_21_juni_2016.pdf (Dilihat Pada Tanggal 6 Januari 2017 )
} 
2. Evaluasi dan pemetaan (memetakan inventarisasi perda/raperda dan kajiannya)

3. Pembinaan perancang peraturan perundangundangan

a. Penyusunan Kebijakan Teknis;

b. Pembinaan pengembangan dan pola karier perancang;

c. Pembinaan tim penilaiangka kredit perancang.

Kanwil sebagai perpanjangan tangan Kemenkumham berperan sebagai pembina hukum dan sekaligus sebagai koordinator harmonisasi dan sinkronisasi rancangan peraturan perundang-undangan di daerah. Pelaksanaan tugas dan fungsi Kanwil pada dasarnya merupakan implementasi dan konsekuensi logis dari pelaksanaan tugas Menteri di daerah, oleh karena itu Kanwil harus serius mempersiapkan diri serta memiliki tenaga perancang hukum yang berkualitas agar dapat melaksanakan tugas yang diamanatkan oleh ketentuan di atas.

Di dalam Pasal 2 Peraturan Menteri Hukum dan HAM Nomor 28 Tahun 2014 Tentang Organisasi dan Tata Kerja Kantor Wilayah Kementerian Hukum dan HAM RI disebutkan bahwa Kanwil mempunyai tugas melaksanakan tugas dan fungsi Kemenkumham dalam wilayah provinsi berdasarkan kebijakan Menteri dan ketentuan peraturan perundang-undangan. Lebih lanjut dalam Pasal 3 disebutkan pula bahwa Kanwil menyelenggarakan fungsi: a) Pengorganisasian perencanaan, pengendalian program dan pelaporan; b) Pelaksanaan pelayanan di bidang administrasi hukum umum, hak kekayaan intelektual, dan pemberian informasi hukum; c) Pelaksanaan fasilitasi perancangan produk hukum daerah, pengembangan budaya hukum dan penyuluhan hukum, serta konsultasi dan bantuan hukum; d) Pengoordinasian pelaksanaan operasional unit pelaksana teknis di lingkungan Kementerian Hukum dan Hak Asasi Manusia di bidang keimigrasian dan bidang pemasyarakatan; e) Penguatan dan pelayanan hak asasi manusia dalam rangka mewujudkan penghormatan, pemenuhan, pemajuan, perlindungan dan penegakan hak asasi manusia; dan f) Pelaksanaan urusan administrasi di lingkungan Kantor Wilayah.

Lebih lanjut dalam Pasal 46 disebutkan bahwa Bidang Hukum mempunyai tugas melaksanakan pembinaan dan pengendalian pelaksanaan tugas teknis, kerja sama, pemantauan, evaluasi, serta penyusunan laporan pelaksanaan tugas teknis di bidang pelayanan dokumentasi dan informasi hukum, penyiapan bahan fasilitasi perencanaan dan penyusunan produk hukum daerah, dan pengembangan Perancang Peraturan Perundang-undangan di wilayah, serta bimbingan teknis. Kemudian dalam Pasal 47 disebutkan bahwa untuk melaksanakan tugas sebagaimana dimaksud dalam Pasal 46, Bidang Hukum menyelenggarakan fungsi (a) Pelaksanaan pembinaan dan pengendalian pelaksanaan tugas teknis di bidang pelayanan dokumentasi dan informasi hukum, penyiapan bahan fasilitasi pembentukan produk hukum daerah, dan pengembangan Perancang Peraturan Perundang-undangan di wilayah serta bimbingan teknis. Lebih teknis dalam Pasal 49 Ayat (2) disebutkan bahwa Subidang Dokumentasi dan Informasi Hukum mempunyai tugas melakukan penyiapan bahan pembinaan dan pengendalian pelaksanaan tugas teknis, kerja sama, pemantauan, evaluasi, serta penyusunan laporan pelaksanaan tugas teknis di bidang pelayanan dokumentasi dan informasi hukum dengan pemerintah provinsi dan kabupaten/kota.

Kegiatan Kanwil dalam rangka melakukan fasilitasi pembentukan produk hukum daerah terdiri atas:

1. Mediasi dan konsultasi;

2. Penyusunan dan harmonisasi produk hukum daerah;

3. Inventarisasi produk hukum daerah;

4. Pembinaan perancang peraturan perundangundangan di wilayah.

Dalam rangka melaksanakan tugas dan fungsi Kanwil di bidang fasilitasi pembentukan produk hukum daerah, maka kegiatan inventarisasi produk hukum daerah menjadi sangat penting sebagai dasar untuk mengembangkan pengelolaan dan pelayanan database produk hukum daerah. Dengan tertatanya database pada gilirannya diharapkan dapat meningkatkan peran Kanwil dalam bidang fasilitasi pembentukan produk hukum daerah.

\section{Rumusan Masalah}

Berdasarkan uraian latar belakang masalah diatas, maka dalam kajian ini dirumuskan beberapa permasalahan yang akan dijawab, yaitu:

1. Bagaimana pengelolaan dan pelayanan database peraturan perundang-undangan di daerah yang sudah dilaksanakan selama ini?

2. Bagaimana peran Kanwil Kemenkumham dalam pengelolaan dan pelayanan 
database peraturan perundang-undangan di daerah?

3. Faktor-faktor penghambat dalam pengelolaan dan pelayanan database peraturan perundang-undangan di daerah ?

\section{Tujuan}

1. Untuk mengetahui dan menganalisis bagaimana pengelolaan dan pelayanan peraturan perundang-undangan di daerah yang sudah dilaksanakan selama ini.

2. Untuk mengetahui dan menganalisis peran Kanwil Kemenkumham dalam pengelolaan dan pelayanan database peraturan perundang-undangan di daerah.

3. Untuk mengetahui dan menganalisis faktorfaktor penghambat dalam pengelolaan dan pelayanan database peraturan perundangundangan di daerah.

\section{Metodologi Penelitian}

\section{Pendekatan}

Penelitian/kajian ini didekati dengan pendekatan kualitatif dan pendekatan kuantitatif. Pendekatan kualitatif dilakukan sebagai strategi untuk mengumpulkan dan memanfaatkan semua informasi yang terkait dengan pokok permasalahan. Pendekatan kuantitatif dilakukan secara terbatas untuk mengukur tingkat kecenderungan dari jawaban-jawaban informan dan responden yang terkait dengan pokok permasalahan, dengan pentabulasian melalui sistem tally dan distribusi frekuensi, sehingga dapat diketahui gambaran data secara faktual.

\section{Metode Pengumpulan Data}

Data yang digunakan dalam kegiatan kajian ini adalah data sekunder yang dikumpulkan berdasarkan penelusuran literatur (library research) dan data primer (field research) yang dikumpulkan dari setiap subjek data (unit/orang). Sedangkan alat pengumpulan data primer adalah angket yang berisi daftar pertanyaan secara tertulis yang ditujukan kepada responden dan Pedoman Wawancara yang ditujukan kepada Informan.

\section{Teknik Penarikan Sampel}

Sampel yang akan diambil dari keseluruhan kelompok/unit mengikuti "hukumnon probability", dengan menggunakan teknik purposive judgment sampling. Kriteria penarikan sampel secara sengaja ini dengan mempertimbangan faktor-faktor: a. Kecenderungan daerah dengan
Perda/Perkada Kab/Kota yang dicabut/direvisi oleh Menteri Dalam Negeri; b. Memperhatikan keterwakilan wilayah barat, tengah dan timur Indonesia. Data kecenderungan Perda/Perkada Kab/Kota yang dicabut/direvisi Menteri Dalam Negeri sampai tahun 2016, adalah sebagai berikut :

Tabel 1. Perda/Perkada Kab/Kota yang dicabut/direvisi Menteri Dalam Negeri sampai tahun 2016

\begin{tabular}{|c|c|c|c|c|}
\hline NO & PROPINSI & $\begin{array}{c}\text { Rendah } \\
(1-50)\end{array}$ & $\begin{array}{c}\text { J U M L A H } \\
\text { Sedang } \\
(51-100)\end{array}$ & $\begin{array}{c}\text { Tinggi } \\
>100\end{array}$ \\
\hline 1. & DKI Jakarta & 2 & & \\
\hline 2. & Kalimantan Utara & 4 & & \\
\hline 3. & Gorontalo & 4 & & \\
\hline 4. & Sulawesi Barat & 10 & & \\
\hline 5. & Sulawesi Utara & 11 & & \\
\hline & Maluku & 17 & & \\
\hline 7. & Maluku Utara & 17 & & \\
\hline 8. & Papua Barat & 17 & & \\
\hline 9. & Bali & 22 & & \\
\hline 10. & Banten & 23 & & \\
\hline 11. & Kepulauan Riau & 25 & & \\
\hline 12. & Papua & 25 & & \\
\hline 13. & Sulawesi Tengah & 26 & & \\
\hline 14. & Lampung & 28 & & \\
\hline 15. & Bengkulu & 28 & & \\
\hline 16. & Bangka Belitung & 38 & & \\
\hline 17. & NTT & 39 & & \\
\hline 18. & Jambi & 39 & & \\
\hline 19. & Yogyakarta & 41 & & \\
\hline 20. & Sulawesi Tenggara & 44 & & \\
\hline 21. & Nusa Tenggara Barat & 44 & & \\
\hline 22. & Riau & 49 & & \\
\hline 23. & Sumatera Barat & & 53 & \\
\hline 24. & Kalimantan Timur & & 57 & \\
\hline 25. & Sumatera Selatan & & 57 & \\
\hline 26. & Kalimantan Selatan & & 59 & \\
\hline 27. & Nangroe Aceh Darussalam & & 59 & \\
\hline 28. & Kalimantan Barat & & 64 & \\
\hline 29. & Kalimantan Tengah & & 69 & \\
\hline 30. & Sulawesi Selatan & & & 115 \\
\hline 31. & Jawa Tengah & & & 118 \\
\hline 32. & Sumatera Utara & & & 127 \\
\hline 33. & Jawa Barat & & & 133 \\
\hline 34. & Jawa Timur & & & 136 \\
\hline
\end{tabular}

Klasifikasi rendah, sedang dan tinggi dapat dilihat dalam data di bawah ini:

Grafik 1. Klasifikasi rendah, sedang dan tinggi Perda/Perkada Kab/Kota yang dicabut/direvisi Menteri Dalam Negeri sampai tahun 2016

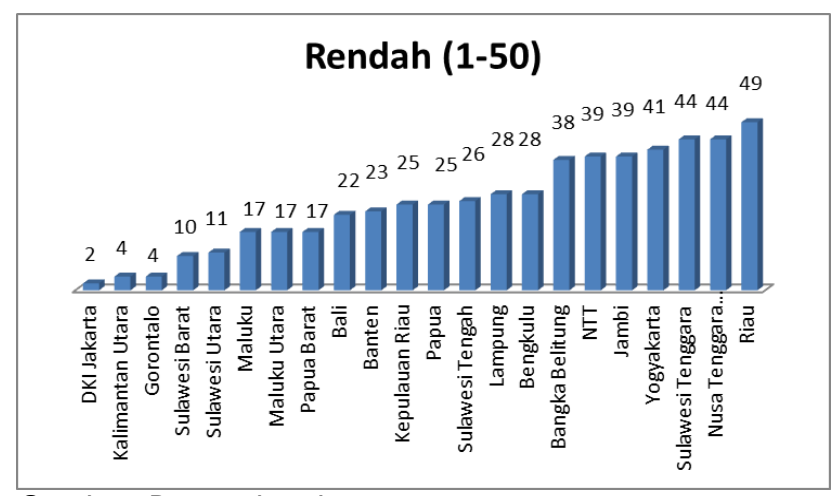

Sumber: Data sekunder 


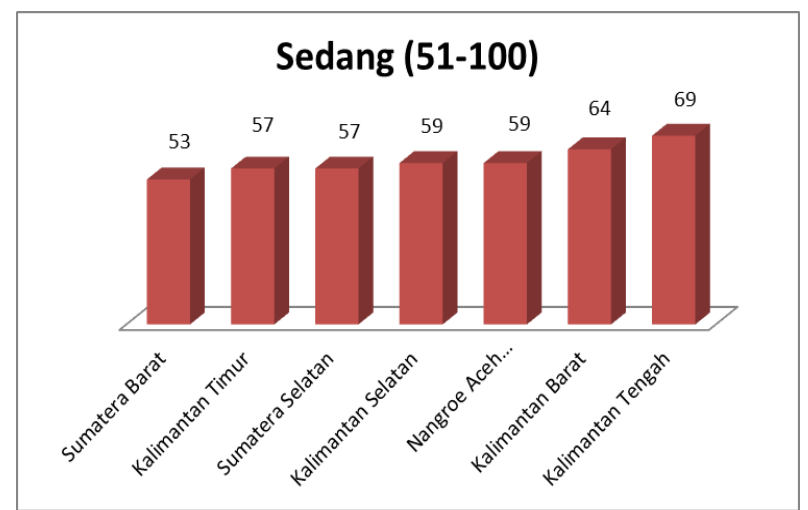

Sumber: Data sekunder

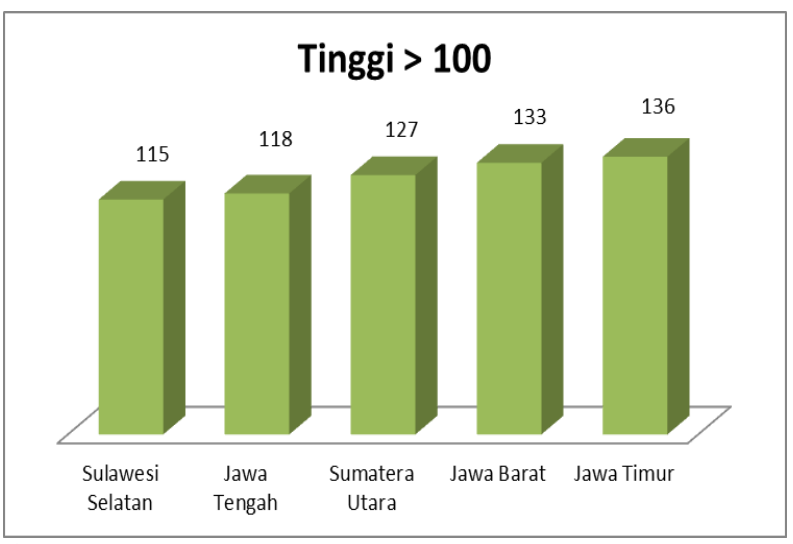

Sumber: Data sekunder

\section{PEMBAHASAN}

\section{Pengelolaan dan Pelayanan Database Peraturan Perundang-Undangan di Daerah}

Pengelolaan merupakan terjemahan dari kata "management", terbawa oleh derasnya arus penambahan kata pungut ke dalam bahasa Indonesia, istilah Inggris tersebut lalu di Indonesia menjadi manajemen. Manajemen berasal dari kata to manage yang artinya mengatur, pengaturan dilakukan melalui proses dan diatur berdasarkan urutan dari fungsi-fungsi manajemen. Jadi manajemen itu merupakan suatu proses untuk mewujudkan tujuan yang diinginkan melalui aspek-aspeknya antara lain planning, organaising, actuating, dan controling. Dalam kamus Bahasa Indonesia lengkap disebutkan bahwa pengelolaan adalah proses atau cara perbuatan mengelola atau proses melakukan kegiatan tertentu dengan menggerakkan tenaga orang lain, proses yang membantu merumuskan kebijaksanaan dan tujuan organisasi atau proses yang memberikan pengawasan pada semua hal yang terlibat dalam pelaksanaan kebijaksanaan dan mencapai tujuan. ${ }^{5}$ Menurut Suharsimi Arikunta

\footnotetext{
${ }^{5}$ Daryanto, Kamus Indonesia Lengkap,(Surabaya: Apollo, 1997), hlm 348.
}

pengelolaan adalah subtantifa dari mengelola, sedangkan mengelola berarti suatu tindakan yang dimulai dari penyusunan data, merencanakan, mengorganisasikan, melaksanakan, sampai dengan pengawasan dan penilaian. Dijelaskan kemudian pengelolaan menghasilkan sesuatu dan sesuatu itu dapat merupakan sumber penyempurnaan dan peningkatan pengelolaan selanjutnya. $^{6} \quad$ Marry Parker Follet (1997) mendefinisikan pengelolaan adalah seni atau proses dalam menyelesaikan sesuatu yang terkait dengan pecapaian tujuan. Dalam penyelesaian akan sesuatu tersebut, terdapat tiga faktor yang terlibat:

1.Adanya penggunaan sumber daya organisasi, baik sumber daya manusia maupun faktorfaktor produksi lainnya;

2.Proses yang bertahap mulai dari perencanaan, pengorganisasian, pengarahan dan pengimplementasian, hingga pengendalian dan pengawasan;

3. Adanya seni dalam penyelesaian pekerjaan. ${ }^{7}$

Drs. M. Manulang dalam bukunya Dasardasar Manajemen mengatakan istilah pengelolaan (manajemen) mengandung tiga pengertian, yaitu: pertama, manajemen sebagai suatu proses, kedua, manajemen sebagai kolektifitas orang-orang yang melakukan aktifitas manajemen dan yang ketiga, manajemen sebagai suatu seni (art) dan sebagai suatu ilmu. Menurut pengertian yang pertama yakni manajemen sebagai suatu proses, artinya pelaksanaan suatu kegiatan dengan tujuan tertentu dan diawasi. Sedangkan menurut pengertian yang kedua, manjemen adalah kolektivitas orang-orang yang melakukan aktivitas manajemen. Menurut pengertian yang ketiga, manajemen adalah suatu seni atau ilmu perencanaan, pengorganisasian, penyusunan, pengarahan, dan pengawasan dari pada sumber daya manusia untuk mencapai tujuan yang sudah ditetapkan terlebih dahulu. ${ }^{8}$ Jadi dapat disimpulkan bahwa pengelolaan (manajemen) adalah suatu cara atau proses yang dimulai dari perencanaan, pengorganisasian, pengawasan dan evaluasi untuk mencapai suatu tujuan yang telah ditentukan agar berjalan efektif dan efisien.

\footnotetext{
${ }^{6}$ Suharsimi Arikunta, Pengelolaan Kelas dan Siswa, (Jakarta: Rajawali, 1988), hlm 8.

Erni Tisnawati Sule dan Kurniwan Saefullah, Pengantar Manajemen, (Jakarta: Kencana Perdana MediaGoup, 2009), hlm 6.

${ }^{8}$ M. Manulang, Dasar-dasar Manajemen, (Jakarta: Ghalia Indonesi, 1990), hlm 15.
} 
Membicarakan pelayanan publik secara konseptual juga tidak bisa dilepaskan dari manajemen. Manajemen harus ditegakkan. Rencana atau peraturan sebagai produk manajemen, misalnya, harus ditaati oleh setiap orang atau masyarakat yang berkaitan dengan rencana atau peraturan yang bersangkutan. Setiap keputusan harus cukup kuat untuk mengikat setiap orang yang terlibat, secara tegas atau dengan paksaan (kekuatan fisik). Setiap peraturan atau keputusan bersifat mengikat, dan oleh karena itu orang tidak boleh berbuat menurut kehendak hatinya sendiri. Oleh karena itu manajemen memerlukan faktor lain, yaitu kekuasaan (power). Karena kekuasaan itu dilancarkan dari belakang meja (burreau), maka kekuasaan itu disebut juga birokrasi. ${ }^{9}$ Sadar atau tidak sadar setiap warga negara selalu berhubungan dengan aktivitas birokrasi pemerintahan. Tiada henti orang harus berurusan dengan birokrasi, sejak berada dalam kandungan sampai meninggal dunia. Dalam setiap sendi kehidupan kalau seseorang tinggal di sebuah tempat dan melakukan interaksi sosial dengan orang lain serta merasakan hidup bernegara, keberadaan birokrasi pemerintahan menjadi suatu conditio sine quanon yang tidak bisa ditawar-tawar lagi dan ia akan selalu menentukan aktivitas mereka. Kenyataan ini juga terjadi di Indonesia. ${ }^{10}$

Dewasa ini masyarakat begitu peka dengan istilah birokrasi. Hampir semua lapisan sosial masyarakat mengenal sebutan birokrasi, terutama di kalangan terdidik. Sayangnya persepsi yang muncul ketika orang mendengar perkataan birokrasi seringkali menyesatkan. Hal yang tergambar di benak orang jika membicarakan birokrasi ialah urusan-urusan menjengkelkan berkenaan dengan pengisian formulir-formulir, proses perolehan izin yang melalui banyak kantor secara berantai, aturanaturan ketat yang mengharuskan seseorang melewati banyak sekat-sekat formalitas, dan sebagainya. Barangkali kita memerlukan terminologi baru untuk mengangkat citra tersebut atau mendudukkan peristilahan pada proporsi sebenarnya. Seperti telah diutarakan di atas, birokrasi sesungguhnya dimaksudkan sebagai sarana bagi pemerintah yang berkuasa untuk melaksanakan pelayanan publik sesuai dengan aspirasi masyarakat. ${ }^{11}$ Dalam melaksanakan kebijakan-kebijakan publik, para

\footnotetext{
${ }^{9}$ Taliziduhu Ndraha, Konsep Administrasi dan Administrasi di Indonesia,(Jakarta: Bina Aksara, 1989), hlm 72.

${ }^{10}$ Wahyudi Kumorotomo, Etika Administrasi Negara, (Jakart: RajaGrafindo Persada), hlm 155.

${ }_{1}^{1}$ Ibid, hlm 73.
}

pembuat keputusan tidak akan terlepas dari kepentingan umum baik dalam pengertian normatif maupun praktis. Namun, sayangnya pembicaraan tentang kepentingan umum dalam kenyataan lebih banyak diungkapkan dengan retorika-retorika atau slogan-slogan tanpa merujuk kepada kaidah-kaidah normatif yang jelas atau tanpa melihat contoh kasus empiris dalam praktik administrasi negara. Ketidakpastian konsep dan ketidakjelasan acuan itu acapkali mengakibatkan kekeliruan interpretasi, perbedaan persepsi atau kesalahpahaman diantara para akademisi maupun para praktisi. ${ }^{12}$

Untuk membahas kepentingan umum dalam konteks etika kebijakan publik, kita harus membahas etika individual maupun etika sosietal (societal ethics) ${ }^{13}$. Etika individual menyangkut standar perilaku profesional bagi birokrat atau administrator. Sedangkan etika sosietal merujuk kepada tujuan-tujuan yang dicita-citakan oleh masyarakat yang merupakan pedoman bagi arah kebijakan publik. Pada tataran generalisasi yang tertinggi, kita dapat mengatakan bahwa keputusan-keputusan publik harus memaksimalkan manfaat dan meminimalkan biaya. $^{14}$ Dalam tataran ini kepentingan umum yang berorientasi kepada kepentingan masyarakat, akan sangat tergantung dari bagaimana pendapat dan persepsi masyarakat atas kualitas pelayanan publik yang mereka terima, termasuk dan tidak terbatas indikator-indikator yang mempengaruhi seperti: perilaku dan profesionalisme dari para pejabat/pegawai publik yang terlibat di dalamnya. Pada tingkat generalisasi yang lebih rendah, ada beberapa subkriteria yang menyangkut manfaat dan biaya sosietal. Diantaranya 3 (tiga) yang berasosiasi dengan nilai-nilai politis dan disingkat dengan $3 \mathrm{P}$, yang terdiri dari public participation (partisipasi masyarakat), predictibality (kepastian layanan), dan procedural due process (keadilan prosedural). Partisipasi masyarakat dapat dinilai dari keterlibatan kelompok-kelompok kepentingan, dan segenap unsur-unsur masyarakat didalam pengambilan keputusan secara demokratis. Kepastian layanan berarti bahwa pengambilan keputusan dilaksanakan berdasarkan kriteria yang objektif sehingga jika

\footnotetext{
${ }^{12} \mathrm{lbid}, \mathrm{hlm} 361$.

${ }^{13}$ Konsep sosietal disini merujuk kepada hak milik kolektif dalam arti kebahagiaan terbesar bagi jumlah yang terbesar (the greatest happiness for the greates number) sebagaimana telah diuraikan oleh para filsuf utilitarian seperti Jeremy Bentham dan John Stuart Mill atau para pendukung prgamatisme seperti John Dewey.

${ }^{4}$ Op. Cit, hlm 361.
} 
seseorang mendapat keputusan tertentu setelah memenuhi kriteria yang ditetapkan maka orang lain pun akan memperoleh keputusan yang sama kalau memang memenuhi kriteria tersebut. Sementara itu, keadilan prosedural berarti bahwa andaikata seorang warga negara mendapat perlakuan tidak adil, maka dia berhak untuk mengetahui apa kesalahannya, untuk mengetahui buktibuktinya, untuk mengajukan pembelaan, dan berhak memperoleh kesempatan untuk setidaktidaknya mengajukan satu kali banding. Setiap orang hendaknya memperoleh kesempatan seperti itu secara sama. ${ }^{15}$

Sebagaimana diamanatkan dalam Peraturan Presiden Nomor 33 Tahun 2012, Instansi sebagaimana dimaksud dalam Pasal 4 Ayat (3) huruf a wajib membentuk organisasi jaringan dokumentasi dan informasi hukum di lingkungannya. Ayat (2) Anggota JDIHN sebagaimana dimaksud dalam Pasal 4 Ayat (3) huruf a angka 1 dan angka 2, bertindak sebagai pusat jaringan dokumentasi dan informasi hukum di lingkungannya. Ayat (3) Pemerintah Provinsi sebagaimana dimaksud dalam Pasal 4 Ayat (3) huruf a angka 4 bertindak sebagai pusat jaringan dokumentasi dan informasi hukum di wilayahnya. Pasal 6 ayat (1) Kantor Wilayah Kementerian Hukum dan Hak Asasi Manusia merupakan instansi vertikal di bidang hukum sebagai pusat layanan hukum di daerah dan mempunyai kewajiban untuk memberikan pelayanan dokumentasi dan informasi hukum. Ayat (2) Kantor Wilayah Kementerian Hukum dan Hak Asasi Manusia bersama dengan Pemerintah Provinsi melakukan pembinaan dan pengembangan jaringan dokumentasi dan informasi hukum di wilayahnya. Pasal 7 Pusat JDIHN dan Anggota JDIHN sebagaimana dimaksud dalam Pasal 4 Ayat (2) dan Ayat (3) wajib melakukan Pengelolaan Dokumentasi dan Informasi Hukum dengan menyediakan sarana dan prasarana, serta sumber daya manusia, dan anggaran. Pasal 8 (1) Pusat JDIHN bertugas melakukan pembinaan, pengembangan, dan monitoring pada Anggota JDIHN yang meliputi:
a. Organisasi;
b. Sumber Daya Manusia;
c. Koleksi Dokumen Hukum;
d. Teknis pengelolaan;
e. Sarana prasarana;
f. Pemanfaatan teknologi informasi dan komunikasi.

Dari ketentuan d iatas secara implisit terlihat belum ada kejelasan terkait instansi mana yang berwenang melakukan pengelolaan jaringan data dan informasi hukum di daerah. Di satu sisi Pemerintah Provinsi bertindak sebagai pusat jaringan dokumentasi dan informasi hukum di wilayahnya. Di sisi lain juga dikatakan bahwa Kanwil Kemenkumham merupakan instansi vertikal di bidang hukum sebagai pusat layanan hukum di daerah dan mempunyai kewajiban untuk memberikan pelayanan dokumentasi dan informasi hukum. Termasuk kketentuan yang menyebutkan Kanwil Kemenkumham bersama dengan Pemerintah Provinsi melakukan pembinaan dan pengembangan jaringan dokumentasi dan informasi hukum di wilayahnya. Menurut naturenya, mengingat Perda adalah bagian dari salah satu sumber hukum dalam hirarki peraturan perundang-undangan, maka keberadaan jaringan data dan informasi hukum di Kanwil Kemenkumham perlu menjadi perhatian. Hal ini mengingat secara mutatis mutandis kewenangan pembangunan bidang hukum dan hak asasi manusia berada di Kemenkumham sampai ke Kanwil. Namun demikian, mengingat Program Pembangunan Peraturan dalam Program Legislasi Daerah, perencanaannya ada di Pemda, maka sudah barang tentu dalam prakteknya database Perda relatif lebih lengkap di Pemda. Oleh karenanya pengelolaan dan pelayanan database peraturan perundang-undangan di Kanwil perlu menjadi perhatian sekaligus pertanyaan, apakah tetap melakukan pengelolaan sekaligus pelayanan, atau lebih mengedepankan fungsi pengendalian atas pengelolaan dan pelayanan database Perda yang sudah relatif baik dikelola oleh pihak Pemda. Hal ini terlihat ketika ditanyakan kepada responden instansi mana yang seharusnya berkewajiban melakukan pengelolaan dan pelayanan database peraturan perundang-undangan di daerah (Perda dan Perkada), mayoritas responden menjawab Pemda, sebagaimana dalam grafik dibawah ini:

\footnotetext{
${ }^{15}$ Op. Cit, hlm 363. 


\section{Grafik 2. Instansi yang berkewajiban melakukan pengelolaan dan pelayanan database peraturan perundang-undangan di daerah}

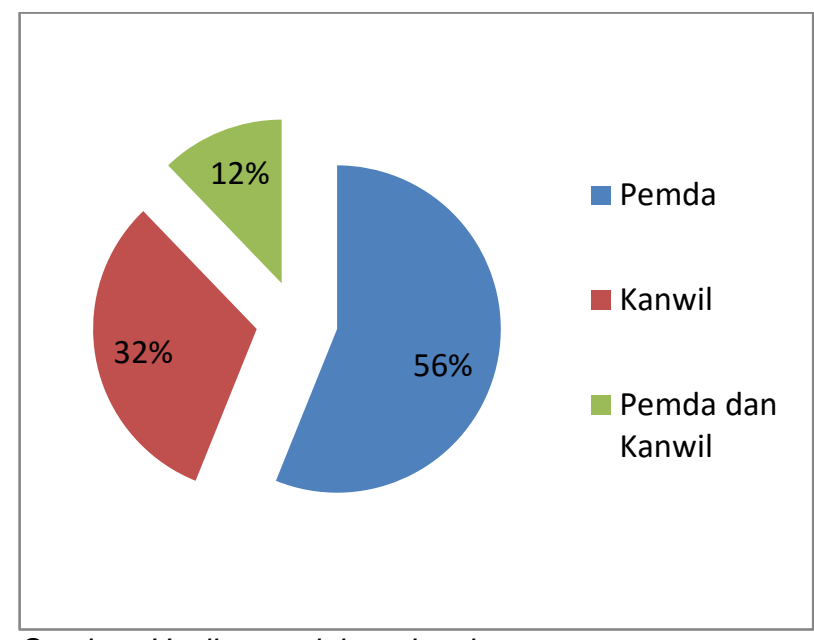

Sumber: Hasil pengolahan data lapangan

Mayoritas responden (56\%) menjawab Pemda dengan berbagai alasan, seperti:

1. Pusatnya pembentukan produk hukum daerah mulai dari penyusunan, harmonisasi hingga pengundangan;

2. Menjadi tempat penyusunan dan perumusan produk hukum daerah, sehingga Pemda lah yang harus mendokumentasikan dan mensosialisasikannya kepada masyarakat;

3. Bahan Perda lebih mudah diperoleh di Pemda karena penyusunannya ada di Pemda;

4. Setiap PerdaKab/Kota diberi nomor registrasi di Biro Hukum sehingga lebih memudahkan dalam pengumpulan Perda/Perkada;

5. Pemda Provinsi adalah perpanjangan tangan Kemendagri di daerah.

Meskipun hanya $32 \%$ yang menjawab

Kanwil Kemenkumham, menarik untuk mencermati alasan responden yang beralasan karena instanasi induk JDIHN ada di BPHN yang merupakan bagian dari Kemenkumham dan Kanwil merupakan perpanjangan tangan BPHN di daerah. Sedangkan $12 \%$ responden menjawab ada baiknya Pemda dan Kanwil kemenkumham secara bersama-sama melakukan pengelolaan dan pelayanan database peraturan perundang-undangan daerah.

Namun demikian, meskipun mayoritas responden berpendapat bahwa yang berkewajiban melakukan pengelolaan dan pelayanan peraturan perundang-undangan di daerah adalah Pemda, kualitasnya belum maksimal, hal ini sebagaimana terlihat dalam grafik dibawah ini:
Grafik 3. Kualitas pengelolaan dan pelayanan database produk hukum daerah oleh Pemda

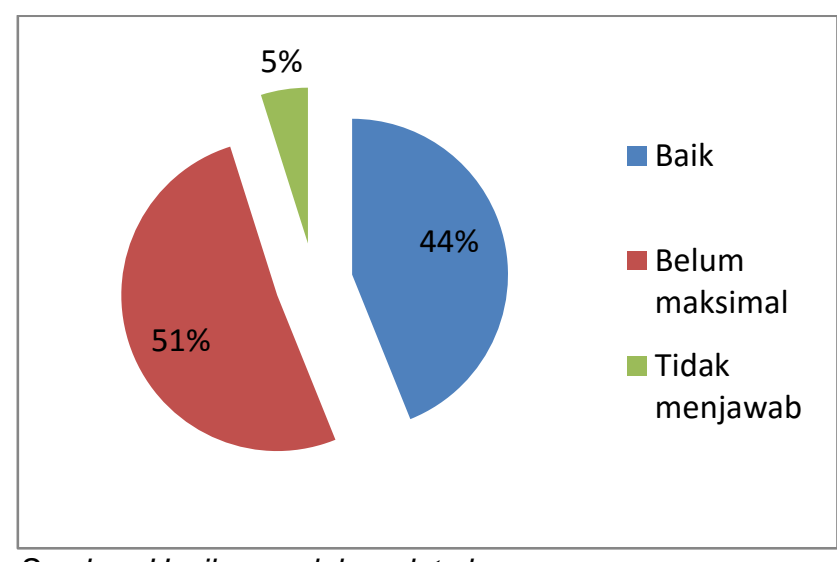

Sumber: Hasil pengolahan data lapangan

Mayoritas responden (51\%) menjawab bahwa pengelolaan dan pelayanan database peraturan perundang-undangan di daerah belum maksimal karena masih banyak produk hukum daerah yang belum di uploud. Sedangkan $44 \%$ menjawab bahwa pengelolaan dan pelayanan database peraturan perundang-undangan di daerah sudah baik.Terkait jumlah produk hukum daerah yang belum diupload tentu perlu kajian lebih lanjut.

\section{Peran Kantor Wilayah Kemenkumham Dalam Pengelolaan dan Pelayanan Database}

Arus globaliasi teknologi di berbagai bidang kegiatan membawa dampak positif bagi perkembangan informasi, khususnya teknologi informasi.Teknologi canggih baik berupa perangkat keras maupun perangkat lunak menjanjikan bagi pemenuhan kebutuhan informasi. Informasi hukum yang lengkap, akurat, tepat sesuai dengan kebutuhkan serta cepat didapat sangat diharapkan keberadaannya. Sampai dengan saat ini informasi masih memegang peranan penting di dunia karena setiap kegiatan selalu membutuhkan informasi. Tanpa diawali adanya informasi yang lengkap dan akurat, maka suatu kegiatan apapun juga akan mendapatkan kesulitan, demikian halnya dengan Informasi hukum. Pentingnya informasi hukum bagi kehidupan manusia mendorong orang atau berbagai kalangan dan instansi, khususnya pengelola dokumentasi hukum untuk melakukan pengelolaan data/dokumentasi yang dimiliki, seperti peraturan perundang-undangan dan bahan hukum lainnya. Peraturan perundang-undangan merupakan suatu data yang banyak dicari dan dibutuhkan, karena selain penting juga sebagai dasar untuk menjalankan kehidupan berbangsa dan bernegara.Peraturan perundang-undangan dan 
bahan hukum lainnya tersebut keberadaannya perlu mendapatkan perhatian dan pengolahan secara khusus, karena selain masih tersebar di berbagai instansi juga perlu penataan yang baik.

Untuk mewujudkan suatu sistem pendayagunaan bersama peraturan perundangundangan dan bahan dokumentasi hukum lainnya secara tertib, terpadu dan berkesinambungan serta pemberian pelayanan informasi hukum secara mudah, cepat, tepat, lengkap dan akurat maka diperlukan adanya suatu database dengan pengelolaan teknologi informasi yang tepat guna, yang nantinya berfungsi sebagai bank data yang terolah dan dapat terintegrasi dengan baik.

Secara teknis data adalah suatu kumpulan kata, kalimat tulisan, pesan, sandi, gambar dan lain-lain yang diolah sehingga menjadi informasi yang mengandung arti bagi penyampai maupun penerima pesan. Sedangkan yang dimaksud database adalah kumpulan data/file yang dikemas dalam pangkalan data secara elektronik dan disatukan ke dalam program aplikasi sesuai dengan kebutuhan yang diinginkan sehingga data tersebut terintegrasi dengan baik, data yang telah disatukan ke program aplikasi disebut database.

Aplikasi adalah suatu program untuk mengolah dan membangun database atau pangkalan data. Program aplikasi sangat beraneka ragam, sebagaimana yang digunakan BPHN sebagai Pusat Jaringan Dokumentasi dan Informasi Hukum Nasional. BPHN, pada Tahun 1985 telah membangun aplikasi yang dinamakan KHAIDAH (Khasanah Informasi Dan Anotasi Hukum), aplikasi ini digunakan untuk menyimpan data dalam bentuk indexing (katalog) peraturan perundang-undangan. Tahun 1994 menggunakan aplikasi Premise untuk mengolah dan menghimpun data peraturan perundang-undangan tingkat pusat dalam database yang disertai naskah lengkap peraturan perundang-undangan dalam versi CD-ROM. Hingga saat ini, telah dikembangkan datanya hingga tahun 2013. Peraturan yang berhasil dihimpun dimulai dari tahun 1945 hingga tahun 2013. Melihat kebutuhan akan pengelolaan database peraturan perundangundangan, maka pada Tahun 2003 BPHN membangun sebuah Grand Design Sistem Informasi Hukum secara elektronik yang direvitalisasi pada tahun 2009 menjadi portal situs bphn.go.id. Kegiatan ini dimaksudkan untuk mewujudkan sistem pangkalan data hukum berbasis jaringan internet. Tujuan pembangunan websitebphn.go.id adalah untuk 12 memberikan pelayanan informasi hukum secara mudah, cepat dan akurat sebagaimana diharapkan oleh banyak pihak utamanya para Anggota Jaringan baik pusat dan daerah. Oleh karena itu BPHN berupaya secara konsisten melakukan pembaharuan data khususnya Peraturan Pusat secara berkala. Dimana peraturan-peraturan tersubut juga dilengkapi dengan hypertextlink dan status akhir dari peraturan dimaksud.

Pada tahun 2009 pengembangan dari portal website yang telah dimiliki, telah dibangun aplikasi pola standar website yang diperuntukkan untuk Anggota Jaringan baik tingkat pusat maupun daerah, langkah ini dimaksudkan untuk memudahkan anggota jaringan dalam mengelola database yang telah mereka miliki dan pengelolaan data peraturan perundang-undangan yang dikeluarkan intansi masing masing. Dalam pengembangannya selanjutnya website yang dibangun tersebut sepenuhnya diserahkan kepada masing-masing Anggota Jaringan. Pembangunan Pola Standar Website Jaringan Data dan Informasi Hukum (JDIH) untuk Anggota Jaringan adalah merupakan hasil rekomendasi Pertemuan Berkala JDIH baik di Pontianak tahun 2005 maupun di Padang tahun 2006 dan telah disetujui di Pertemuan Berkala tahun 2007 di Banjarmasin. Di dalam pengelolaan database website jdih di masing masing Anggota JDIH baik pusat maupun di daerah, yang menjadi dasar hukum pengelolaan Anggota JDIH di tingkat pusat maupun daerah adalah Peraturan Presiden Nomor 33 Tahun 2012 dan standar pengelolaan databasenya menggunakan Peraturan Menteri Hukum dan HAM RI Nomor 2 Tahun 2013. Hal tersebut harus dipatuhi oleh anggota jaringan agar terdapat keseragaman pengelolaan database, yang nantinya menjadi kunci terbentuknya integrasi database peraturan perundang-undangan jdihn.id, yang ke depannya bila seluruh anggota jaringan telah terintegrasi databasenya menjadi satu, akan menjadi google peraturan perundang-undangan di Indonesia.

Pelayanan informasi hukum baik peraturan perundang-undangan maupun informasi hukum lainnya merupakan sarana informasi yang baku untuk menunjang semua aktivitas dan tingkat ilmu pengetahuan. Kemajuan informasi memaksa kita untuk selalu berupaya meningkatkan pelayanan dengan melalui suatu sistem yang lebih efisien dan efektif dengan melakukan perubahan pola pikir dari cara manual ke cara penyajian informasi secara otomasi. Pelayanan dilihat dari segi kegiatan tidak ada standar atau nilai yang 
langsung dilihat dengan panca indera namun pelayanan merupakan suatu jasa sehingga susah untuk mengukur pelayanan yang baik dan hanya dapat dirasakan bagi individu yang memerlukan jasa pelayanan dimaksud. Tugas tersebut bukanlah tugas yang ringan, mengingat keberhasilan suatu kegiatan yang selalu didasari oleh langkah-langkah dalam memberikan pelayanan yang prima, maka upaya-upaya mewujudkan pelayanan informasi hukum yang mudah, cepat, tepat, lengkap, akurat menjadi sangat penting. Untuk itu dengan adanya database peraturan perundangundangan setidaknya dapat melaksanakan kegiatan pelayanan informasi kepada masyarakat secara mudah, murah, cepat, tepat dan lengkap.

Sehubungan dengan hal tersebut tentunya ada beberapa aspek yang harus dipersiapkan, yaitu :

1. Sumber Daya Manusia (Brainware)

SDM merupakan ujung tombak untuk melaksanakan kegiatan dimaksud baik sebagai programmer maupun sebagai tenaga pelayanan informasi. Untuk mempersiapkan SDM yang memadai, dapat juga memanfaatkan tenaga yang ada yaitu dengan membekali pendidikan baik formal/non formal di bidang teknologi. Selain itu SDM dimaksud harus dapat merumuskan suatu masalah yang timbul dalam melaksanakan tugasnya sebagai programmer dan pelayan informasi, karena program yang dibangunya kemungkinan dikemudian hari ada masalah yang timbul baik segi pengoperasiannya maupun pemasukan datanya, dan lain-lainl.

2. Peralatan (Hardware/Software)

Dalam pengolahan dan pelayanan informasi hukum diperlukan peralatan yang canggih sesuai dengan perkembangan teknologi informasi dan komunikasi saat ini.

3. Dana/Biaya yang dibutuhkan

Semua jenis kegiatan apapun harus didukung dengan anggaran yang cukup, karena tidak ada suatu kegiatan dapat terlaksana dengan baik tanpa tersedia dana yang memadai.

Di dalam Pasal 6 Ayat (1) Peraturan Presiden RI Nomor 33 Tahun 2012 Tentang Jaringan Dokumentasi dan Informasi Hukum Nasional mengatur bahwa Kantor Wilayah Kementerian Hukum dan Hak Asasi Manusia merupakan instansi vertikal di bidang hukum sebagai pusat layanan hukum di daerah dan mempunyai kewajiban untuk memberikan pelayanan dokumentasi dan informasi hukum. Ayat (2) Kantor Wilayah Kementerian hukum dan Hak Asasi Manusia bersama dengan Pemerintah Provinsi melakukan pembinaan dan pengembangan jaringan dokumentasi dan informasi hukum di wilayahnya.

Namun demikian, dalam prakteknya, dari hasil kajian menunjukkan bahwa mayoritas responden (57\%) menjawab bahwa peran Kanwil Kemenkumham dalam pengelolaan dan pelayanan database peraturan perundangundangan di daerah belum maksimal. Hal ini disebabkan minimnya SDM, banyak Perda belum diinput ke dalam sistem JDIHN, inventarisasi data masih manual. Sedangkan 14 $\%$ responden menjawab bahwa peran Kanwil Kemenkumham masih sebatas melakukan monitoring anggota jaringan dan mendorong Pemda Provinsi/Kota/Kab untuk update dan melakukan input data yang terhubung dan terintegrasi dengan BPHN. $12 \%$ responden menjawab peran Kanwil selama ini melakukan inventarisasi Prolegda, Perda, Perkada dan berkoordinasi dengan Pemda Kab/Kota. Sekaligus data dimaksud menunjukkan bahwa peran Kanwil Kemenkumham dalam pengelolaan database peraturan perundangundangan di daerah belum maksimal. Hal ini disebabkan pengelolaan yang dilakukan belum menerapkan prinsip-prinsip manajemen secara umum. Betapapun pengelolaan (management), sebagaimana diteorikan Marry Parker Follet, adalah "seni" dalam menyelesaikan pekerjaan, tetapi keterlibatan dan ketersediaan SDM, alatalat kerja dan mekanisme pekerjaan (perencanaan, pengorganisasian, pengarahan, pengendalian dan pengawasan) mutlak diperlukan. Pada akhirnya, keterbatasan SDM, baik jumlah maupun kualitasnya, berdampak pada banyaknya Perda yang belum diinput kedalam sistem JDIHN. Hal ini sebagaimana terlihat dalam grafik dibawah ini: 


\section{Grafik 4. Peran Kanwil Kemenkumham dalam pengelolaan dan pelayanan database peraturan perundang-undangan di daerah}

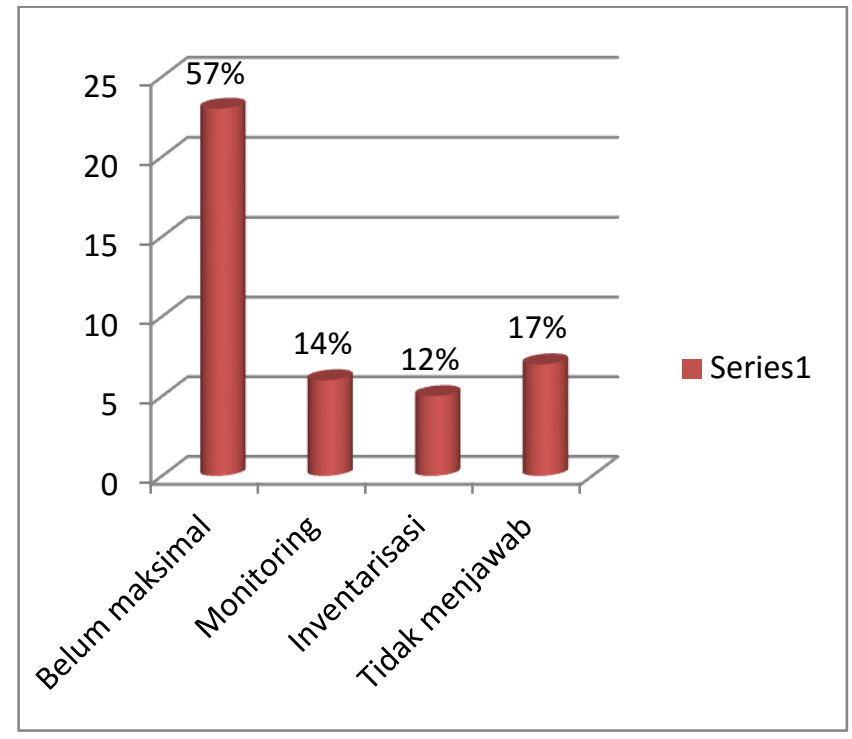

Sumber: Hasil pengolahan data lapangan

Sebagaimana dimaksud dalam Pasal 46 Peraturan Menteri Hukum dan HAM Nomor 28 Tahun 2014 Tentang Organsisasi dan Tata Kerja Kantor Wilayah Kementerian Hukum dan HAM, salah satu tugas dan fungsi Kanwil di bidang Hukum adalah melaksanakan pembinaan dan pengendalian pelaksanaan tugas teknis, kerja sama, pemantauan, evaluasi, serta penyusunan laporan pelaksanaan tugas teknis di bidang pelayanan dokumentasi dan informasi hukum, penyiapan bahan fasilitasi perencanaan dan penyusunan produk hukum daerah, dan pengembangan Perancang Peraturan Perundang-undangan di wilayah, serta bimbingan teknis. Lebih lanjut dalam Pasal 47 untuk melaksanakan tugas sebagaimana dimaksud dalam Pasal 46, Bidang Hukum menyelenggarakan fungsi (a) Pelaksanaan pembinaan dan pengendalian pelaksanaan tugas teknis di bidang pelayanan dokumentasi dan informasi hukum, penyiapan bahan fasilitasi pembentukan produk hukum daerah, dan pengembangan Perancang Peraturan Perundang-undangan di wilayah serta bimbingan teknis. Pasal 49 Ayat (2) Subbidang Dokumentasi dan Informasi Hukum mempunyai tugas melakukan penyiapan bahan pembinaan dan pengendalian pelaksanaan tugas teknis, kerja sama, pemantauan, evaluasi, serta penyusunan laporan pelaksanaan tugas teknis di bidang pelayanan dokumentasi dan informasi hukum dengan pemerintah provinsi dan kabupaten/kota.

Namun demikian dalam prakteknya pelayanan dokumentasi dan informasi hukum yang menjadi tugas dan fungsi Sub Bidang Dokumentasi dan Informasi Hukum belum sepenuhnya berjalan. Mengingat dokumentasi dan informasi hukum selama ini di Kanwil, khususnya peraturan perundang-undangan daerah, umumnya masih diinventarisir secara manual. Padahal BPHN sudah membangun web jdihn.go.id yang sudah terintegrasi dengan Kanwil di seluruh Indonesia. Kondisi ini sungguh memprihatinkan. Seharusnya dengan sistem yang sudah dibangun, Kanwil tinggal melakukan input data manual ke sistem elektronik yang tersedia. Hal ini terlihat mayoritas responden (85\%) menjawab bahwa Kanwil Kemenkumham sudah melakukan inventarisasi produk hukum daerah tetapi secara manual, yang meliputi (content) berupa: Judul Raperda, tahun pelaksanaan, instansi pemrakarsa, produk hukum DRPD, himpunan Perda dan Perkada. Sedangkan yang menjawab Kanwil Kemenkumham sudah melakukan inventarisasi produk hukum daerah secara elektronik hanya $10 \%$, sebagaimana grafik dibawah ini:

\section{Grafik 5. Kanwil Kemenkumham melakukan inventarisasi produk hukum daerah}

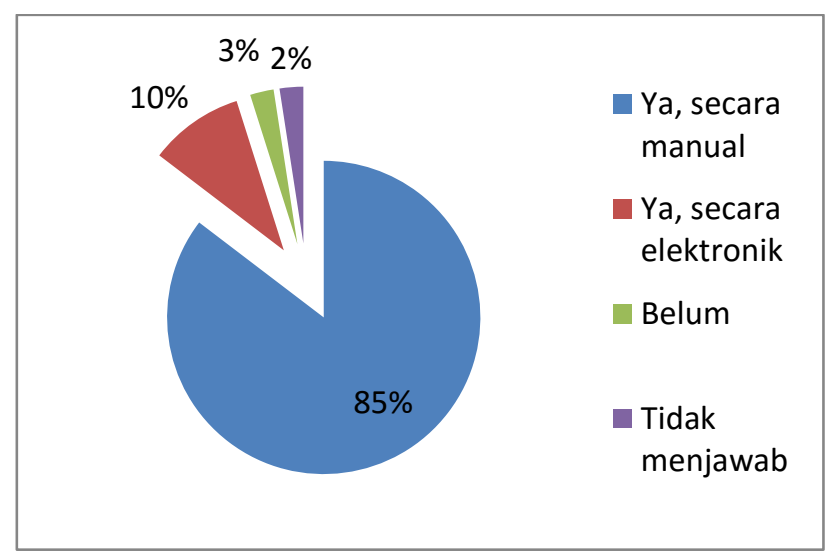

Sumber: Hasil pengolahan data lapangan

\section{Faktor-Faktor Penghambat}

Di dalam konsideran menimbang Peraturan Presiden Nomor 33 Tahun 2012 Tentang Jaringan Dokumentasi dan Informasi Hukum Nasional (JDIHN) dikatakan bahwa dokumentasi dan informasi hukum yang tertata dan terselenggara dengan baik dalam suatu jaringan nasional merupakan bagian yang tidak terpisahkan dalam penyelenggaraan ketata pemerintahan yang baik, bersih, dan bertanggung jawab untuk memenuhi tuntutan masyarakat atas dokumen dan informasi hukum yang dibutuhkan. Untuk mengelola dokumentasi dan informasi hukum yang lengkap, akurat, mudah, dan cepat yang tersebar di 
berbagai instansi pemerintah dan institusi lainnya, perlu membangun kerja sama dalam suatu jaringan dokumentasi dan informasi hukum nasional yang terpadu dan terintegrasi.

Lebih lanjut dalam Pasal 1 disebutkan bahwa JDIHN adalah wadah pendayagunaan bersama atas dokumen hukum secara tertib, terpadu, dan berkesinambungan, serta merupakan sarana pemberian pelayanan informasi hukum secara lengkap, akurat, mudah, dan cepat. Dokumen Hukum adalah produk hukum yang berupa peraturan perundang-undangan atau produk hukum selain peraturan perundang-undangan yang meliputi namun tidak terbatas pada putusan pengadilan, yurisprudensi, monografi hukum, artikel majalah hukum, buku hukum, penelitian hukum, pengkajian hukum, naskah akademis, dan rancangan peraturan perundang-undangan. Sedangkan pengelolaan dokumentasi dan informasi hukum adalah suatu kegiatan pengumpulan, pengolahan, penyimpanan, pelestarian, dan pendayagunaan informasi dokumen hukum.

Tujuan dibentuknya JDIHN, sebagaimana dimaksud dalam Pasal 3, adalah untuk:

1. Menjamin terciptanya pengelolaan dokumentasi dan informasi hukum yang terpadu dan terintegrasi di berbagai instansi pemerintah dan institusi lainnya;

2. Menjamin ketersediaan dokumentasi dan informasi hukum yang lengkap dan akurat, serta dapat diakses secara cepat dan mudah;

3. Mengembangkan kerja sama yang efektif antara pusat jaringan dan anggota jaringan serta antar sesama anggota jaringan dalam rangka penyediaan dokumentasi dan informasi hukum; dan

4. Meningkatkan kualitas pembangunan hukum nasional dan pelayanan kepada publik sebagai salah satu wujud ketatapemerintahan yang baik, transparan, efektif, efisien, dan bertanggung jawab.

Organisasi JDIHN, sebagaimana dimaksud dalam Peraturan Presiden Nomor 33 Tahun 2012, dapat dilihat dalam beberapa pasal di bawah ini:

Pasal 4 Ayat (1) Organisasi JDIHN terdiri atas:

a. Pusat JDIHN; dan

b. Anggota JDIHN.

Ayat (2) Badan Pembinaan Hukum Nasional, Kementerian Hukum dan Hak Asasi Manusia merupakan Pusat JDIHN sebagaimana dimaksud pada ayat (1) huruf a. Ayat (3) Anggota JDIHN sebagaimana dimaksud pada Ayat (1) huruf b terdiri atas: a. Biro hukum dan/atau unit kerja yang tugas dan fungsinya menyelenggarakan kegiatan yang berkaitan dengan Dokumen Hukum pada:

1. Kementerian Negara;

2. Sekretariat Lembaga Negara;

3. LembagaPemerintahan Non Kementerian;

4. Pemerintah Provinsi;

5. Pemerintah Kabupaten/Kota; dan

6. Sekretariat Dewan Perwakilan Rakyat Daerah Tingkat Provinsi dan Kabupaten/Kota;

b. Perpustakaan hukum pada perguruan tinggi negeri dan perguruan tinggi swasta;

c. Lembaga lain yang bergerak di bidang pengembangan dokumentasi dan informasi hukum yang ditetapkan oleh Menteri.

Pasal 5 ayat (1) Pimpinan Instansi sebagaimana dimaksud dalam Pasal 4 Ayat (3) huruf a wajib membentuk organisasi jaringan dokumentasi dan informasi hukum di lingkungannya. Ayat (2) Anggota JDIHN sebagaimana dimaksud dalam Pasal 4 ayat (3) huruf a angka 1 dan angka 2, bertindak sebagai pusat jaringan dokumentasi dan informasi hukum di lingkungannya. Ayat (3) Pemerintah Provinsi sebagaimana dimaksud dalam Pasal 4 Ayat (3) huruf a angka 4 bertindak sebagai pusat jaringan dokumentasi dan informasi hukum di wilayahnya. Pasal 6 Ayat (1) Kantor Wilayah Kementerian Hukum dan Hak Asasi Manusia merupakan instansi vertikal di bidang hukum sebagai pusat layanan hukum di daerah dan mempunyai kewajiban untuk memberikan pelayanan dokumentasi dan informasi hukum. Ayat (2) Kantor Wilayah Kementerian Hukum dan Hak Asasi Manusia bersama dengan Pemerintah Provinsi melakukan pembinaan dan pengembangan jaringan dokumentasi dan informasi hukum di wilayahnya. Pasal 7 Pusat JDIHN dan Anggota JDIHN sebagaimana dimaksud dalam Pasal 4 Ayat (2) dan Ayat (3) wajib melakukan Pengelolaan Dokumentasi dan Informasi Hukum dengan menyediakan sarana dan prasarana, serta sumber daya manusia, dan anggaran. Pasal 8 (1) Pusat JDIHN bertugas melakukan pembinaan, pengembangan, dan monitoring pada Anggota JDIHN yang meliputi:

a. Organisasi;

b. Sumber Daya Manusia;

c. Koleksi Dokumen Hukum;

d. Teknis pengelolaan;

e. Sarana prasarana;

f. Pemanfaatan teknologi informasi dan komunikasi. 
Ayat (2) Pusat JDIHN dalam melaksanakan tugas sebagaimana dimaksud pada Ayat (1) menyelenggarakan fungsi:

a. perumusan kebijakan pembinaan dan pengembangan JDIHN;

b. penyusunandan/atau penyempurnaan pedoman/standar pengelolaan teknis dokumentasi dan informasi hukum;

c. pemberian konsultasi terhadap permasalahan yang dihadapi oleh anggota JDIHN;

d. sosialisasi kebijakan dan pengelolaan teknis dokumentasi dan informasi hukum kepada anggota JDIHN;

e. pembinaan sumber daya manusia pengelola jaringan dokumentasi dan informasi hukum;

f. pusat rujukan dokumentasi dan informasi hukum; dan

g. monitoring dan evaluasi secara berkala setiap 6 (enam) bulan sekali terhadap pelaksanaan tugas dan fungsi anggota JDIHN.

Pasal 9 Ayat (1) Pusat JDIHN dalam melaksanakan tugas dan fungsi sebagaimana dimaksud dalam Pasal 8, dibantu oleh tim pembina dan tim teknis JDIHN yang terdiri dari:

a. Pakar hukum;

b. Pakar dokumentasi; dan

c. Pakar teknologi informasi dan komunikasi.

Ayat (2) Anggota JDIHN dalam melaksanakan tugas sebagaimana

dimaksud pada Ayat (1), menyelenggarakan fungsi:

a. Pengumpulan, pengolahan, penyimpanan, pelestarian, dan pendayagunaan informasi Dokumen Hukum yang diterbitkan instansinya;

b. Pembangunan sistem informasi hukum berbasis teknologi informasi dan komunikasi yang dapat diintegrasikan dengan website pusat JDIHN;

c. Pembinaan dan pengembangan sumber daya manusia pengelola jaringan dokumentasi dan informasi hukum di lingkungannya;

d. Penyediaan sarana dan prasarana pengelolaan jaringan dokumentasi dan informasi hukum di lingkungannya;

e. Pelaksanaan evaluasi mengenai pengelolaan jaringan dokumentasi dan informasi hukum di lingkungannya sekurang-kurangnya 1 (satu) kali dalam setahun; dan

f. Penyampaian laporan setiap tahun di bulan Desember kepada pusat JDIHN.

Pasal 11 Anggota JDIHN dalam melaksanakan tugas dan fungsi sebagaimana dimaksud dalam Pasal 10 wajib berpedoman pada Standar Pengelolaan Dokumentasi dan Informasi Hukum.

BPHN dalam rangka melaksanakan pembinaan hukum telah melakukan berbagai upaya untuk meningkatkan pengelolaan dokumentasi dan informasi hukum, dalam mewujudkan informasi hukum terintegrasi di lingkungan Kementerian Hukum dan HAM. $^{16}$ Pengelolaan dokumen hukum dilakukan dengan cara konvensional maupun otomasi dengan cara memanfaatkan teknologi informasi dan komunikasi yang dapat memberikan kemudahan dan kecepatan bagi pengelola dalam melaksanakan pekerjaannya. Dengan memanfaatkan teknologi informasi dan komunikasi BPHN telah mengembangkan pengelolaan dokumen dan informasi hukum yang terintegrasi baik di tingkat pusat maupun di tingkat daerah. Pengelolaan dokumentasi dan informasi hukum ditingkat pusat dilakukan melalui kerjsama dengan PDII - LIPI untuk mengintegrasikan lima pangkalan data yang ada di BPHN dalam satu klik saja dalam web jdihn.bphn.go.id dapat ditemukan sejumlah referensi mulai dari Buku Hukum, Artikel Majalah Hukum, Artikel Hukum Koran, Peraturan Perundang-undangan maupun koleksi Buku Hukum Peninggalan Hindia Belanda. Informasi hukum yang ada dalam web jdihn.bphn.go.id sampai dengan 1 Desember 2016 sejumlah 12.847 Buku Hukum dan 12.780 Peraturan perundang-undangan Tingkat Pusat yang terdiri dari 1.607 Undang-undang, 174 Peraturan pemerintah Pengganti Undangundang, 175 Undang-undang Darurat, 4.256 Peraturan Pemerintah, 1.626 Peraturan Presiden, 4592 Keputusan Presiden dan 350 Instruksi Presiden. Data dan informasi hukum yang ada di BPHN tersebut dapat diakses secara online dan sudah terintegrasi mulai dari fulltext peraturan perundang-undangan hypertextlink, abstrak undang-undang, status perundang-undangan, peraturan terbaru dan dilengkapi dengan putusan Mahkamah Konstitusi terhadap undang-undang yang diajukan judicial review.

BPHN melalui Pusat Dokumentasi dan Jaringan Informasi Hukum Nasional sedang melakukan penataan database peraturan perundang-undangan dengan cara validasi data peraturan perundang-undangan pusat untuk melaksanakan program pemerintah terkait dengan Revitalisasi dan Reformasi Hukum berdasarkan Nawacita dalam rangka pemulihan kepercayaan publik, keadilan dan kepastian

\footnotetext{
${ }^{16}$ Warta BPHN Tahun Ke III Edisi XIX Okt-Des 2016.
} 
hukum. Selain itu juga telah dikembangkan aplikasi terintegrasi dalam pengelolaan dokumen dan informasi hukum berbasis web di lingkungan Kanwil Kemenkumham seluruh Indonesia dengan Pusat Dokumentasi dan Jaringan Informasi Hukum Nasional. Aplikasi sudah diujicobakan pada tanggal 29 Agustus 2016 di BPHN yang dihadiri oleh 13 (tiga belas) Pengelola Dokumentasi dan Informasi Hukum dari Kanwil Kemenkumham dan 37 (tiga puluh tujuh) pengelola Dokumentasi dan Informasi Hukum dari Unit Eselon I di lingkungan Kemenkumham. Aplikasi pengelolaan dokumen dan informasi hukum berbasis web di lingkungan Kanwil Kemenkumham telah disediakan domain oleh TIM JDIHN Pusat dalam mempercepat proses pengolahan data dan meningkatkan pelayanan dokumetasi dan informasi hukum serta memudahkan proses integrasi data untuk setiap wilayah melalui Aplikasi JDI Hukum Kanwil dengan JDIHN BPHN. Dalam Aplikasi JDI Hukum Kanwil terdapat 6 (enam) konten yaitu: 1. Beranda; 2. Profil JDIHN yang terdiri dari sejarah JDIHN, Visi dan Misi, Tujuan JDIHN, Struktur Organisasi dan Kontak kami; 3. Portal JDIH meliputi 33 (tiga puluh tiga) Kanwil Kemenkumham; 4. Area Anggota untuk anggota perpustakaan yang sudah terdaftar; 5 . Bantuan Pencarian sebagai panduan dalam teknik penelusuran dan proses pencarian informasi hukum; 6. Login untuk pengelola website; 7. SearchEngineMesin pencarian informasi hukum yang meliputi buku, kliping artikel dan peraturan daerah.

Konsep pelayanan publik tidak bisa dilepaskan dari manajemen. Dalam prakteknya hubungan tersebut selalu bisa dibuktikan. Hal ini dapat dilihat dari banyaknya pelayanan publik yang berkualitas dikarenakan manajemen (pengelolaan) yang baik. Kegagalan pelayanan publik, yang berujung pada tidak terpenuhinya apa yang menjadi harapan dapat dipengaruhi berbagai macam faktor. Faktor-faktor yang mempengaruhi tersebut pada dasarnya bisa dijelaskan secara manajemen. Pertama, manajemen sebagai suatu proses adalah bagaimana pelaksanaan peran Kanwil Kemenkumham dalam pengelolaan dan pelayanan database peraturan perundang-undangan di daerah. Peran ini seharusnya bisa diwujudkan apabila aplikasi terintegrasi dalam pengelolaan dokumen dan informasi hukum berbasis web di lingkungan Kanwil Kemenkumham seluruh Indonesia dengan Pusat Dokumentasi dan Jaringan Informasi hukum Nasional BPHN ini dilaksanakan.
Namun demikian, aplikasi yang sudah diujicobakan pada tanggal 29 Agustus 2016 di BPHN yang dihadiri oleh 13 (tiga belas) Pengelola Dokumentasi dan Informasi Hukum dari Kanwil Kemenkumham, tidak diikuti dengan pengawasan dalam pelaksanaannya, karena sampai saat ini mayoritas Kanwil belum melakukan input produk peraturan perundangundangan daerah melalui laman yang berbasis web tersebut. Kedua, pengelolaan dan pelayanan database di Kanwil belum dilakukan secara kolektif sebagai bentuk aktivitas kegiatan modern dan profesional. Faktanya, jaringan dokumentasi dan informasi hukum tidak dikelola oleh pegawai yang memiliki kompetentsi di bidang IT, jumlah pengelola, sarana prasarana serta anggaran masih sangat terbatas. Kendala menajemen yang belum dikelola sebagai aktivitas kegiatan modern, menjadi faktor penghambat dominan temuan hasil kajian. Ketiga, manajemen sebagai suatu seni mencapai tujuan. Seharusnya koordinasi dan komunikasi dengan pihak Pemda, dalam rangka mendapat produk hukum daerah yang akan diinput ke dalam laman jaringan dokumentasi dan informasi hukum, bukan menjadi hambatan, apabila Kanwil dapat membangun hubungan baik dengan daerah sebagai instansi vertikal yang berwenang dan bertanggung jawab di bidang pembangunan hukum dan hak asasi manusia. Faktor-faktor penghambat dimaksud dapat dilihat dalam tabel dibawah ini:

\section{Tabel 2. Faktor-faktor penghambat Kanwil Kemenkumham dalam pengelolaan dan pelayanan database peraturan perundang- undangan di daerah}

\begin{tabular}{|c|c|c|c|}
\hline NO. & JAWABAN & JUMLAH & $\%$ \\
\hline a. & $\begin{array}{l}\text { Kurangnya sarana prasarana, } \\
\text { jaringan internet, kuantitas dan } \\
\text { kualitas SDM dan dukungan } \\
\text { anggaran }\end{array}$ & 25 & 60,97 \\
\hline b. & $\begin{array}{l}\text { Kurangnya koordinasi sehingga sulit } \\
\text { memperoleh data Perda dari Pemda } \\
\text { (Prov/Kab/kota) }\end{array}$ & 5 & 12,20 \\
\hline c. & $\begin{array}{l}\text { Pemda Kab/kota tidak merasa } \\
\text { memiliki kewajiban untuk melaporkan } \\
\text { setiap peraturan perundang- } \\
\text { undangan yang telah ditetapkan }\end{array}$ & 4 & 9,75 \\
\hline d. & "Pengaruh" ke Pemda kurang kuat & 1 & 2,44 \\
\hline e. & $\begin{array}{l}\text { Pemda belum "kooperatif" terhadap } \\
\text { kanwil }\end{array}$ & 1 & 2,44 \\
\hline f. & Tidak menjawab & 5 & 12,20 \\
\hline & TOTAL & 41 & 100 \\
\hline
\end{tabular}




\section{PENUTUP}

\section{Kesimpulan}

Secara eksplisit belum ada kejelasan instansi mana yang berwenang melakukan pengelolaan jaringan data dan informasi hukum di daerah. Di satu sisi Pemerintah Provinsi bertindak sebagai pusat jaringan dokumenatasi dan informasi hukum di wilayahnya. Di sisi lain juga dikatakan bahwa Kantor Wilayah Kementerian Hukum dan Hak Asasi Manusia merupakan instansi vertikal di bidang hukum sebagai pusat layanan hukum di daerah dan mempunyai kewajiban untuk memberikan pelayanan dokumentasi dan informasi hukum. Termasuk ketentuan yang menyebutkan Kantor Wilayah Kementerian Hukum dan Hak Asasi Manusia bersama dengan Pemerintah Provinsi melakukan pembinaan dan pengembangan jaringan dokumentasi dan informasi hukum di wilayahnya.

Peran Kantor Wilayah Kementerian Hukum dan Hak Asasi Manusia dalam pengelolaan dan pelayanan database peraturan perundang-undangan di daerah belum maksimal. Hal ini disebabkan minimnya SDM, banyak Perda yang belum di input kedalam sistem JDIHN dan inventarisasi data masih manual.

Mayoritas Kantor Wilayah Kementerian Hukum dan Hak Asasi Manusia belum menggunakan web jdihn.go.id untuk menginput data Peraturan Daerah dan tidak ada pengawasan dalam pelaksanaannya. Pengelolaan dan pelayanan database di Kanwil belum dilakukan secara kolektif sebagai bentuk aktivitas kegiatan modern dan profesional. Jaringan dokumentasi dan informasi hukum tidak dikelola oleh pegawai yang memiliki kompetentsi di bidang IT, jumlah pengelola, sarana prasarana serta anggaran masih sangat terbatas.

\section{Saran}

1. Melakukan perubahan atas Undang-undang Nomor 12 Tahun 2011 Tentang Pembentukan Peraturan Perundangundangan dengan mewajibkan Pemerintah Daerah untuk menyampaikan setiap produk hukum daerah, khususnya Peraturan Daerah, ke Kantor Wilayah Kementerian Hukum dan HAM. Termasuk melibatkan Kanwil dalam proses pembentukannya.

2. Pusat Jaringan Dokumentasi dan Informasi Hukum Nasional BPHN perlu segera melakukan pendampingan secara sungguh- sungguh terkait pengelolaan database Jaringan Data dan Informasi Hukum di Kanwil. Hal ini mengingat aplikasi web jdihn.bphn.go.id, yang sudah diujicobakan pada tanggal 29 Agustus 2016 dan dihadiri 13 (tiga belas) Pengelola Dokumentasi dan Informasi Hukum Kanwil Kemenkumham, ternyata sampai saat ini belum dikelola dengan baik.

3. Melakukan perubahan atas Peraturan Menteri Hukum dan HAM Nomor 28 Tahun 2014 Tentang Organisasi dan Tata Kerja Kantor Wilayah Kementerian Hukum dan HAM dengan menambah kewenangan Kantor Wilayah Kementerian Hukum dan HAM untuk melakukan analisis setiap produk Peraturan Daerah yang dikeluarkan Pemerintah Daerah.

4. Kantor Wilayah Kementerian Hukum dan HAM dan Pemerintah Daerah, di masa mendatang perlu menyepakati adanya satu pangkalan data peraturan perundangundangan daerah berbasis web yang terhubung dan terintegrasi dengan Kementerian Hukum dan HAM (BPHN dan Direktorat Jenderal Peraturan Perundangundangan). Hal ini untuk memudahkan masyarakat dalam mendapatlan layanan informasih hukum.

5. Kantor Wilayah Kementerian Hukum dan HAM sebagai instansi vertikal pembangunan hukum dan hak asasi manusia sekaligus sebagai pusat layanan dokumentasi dan informasi hukum, secara periodik perlu melakukan koordinasi dan pengendalian database yang ada di Biro Hukum Pemerintah Daerah. Dengan tertatanya produk hukum daerah dengan baik diharapkan dapat memudahkan kegiatan harmonisasi dan sinkronisasi, yang pada gilirannya dapat meminimalisir Perda yang bermasalah.

6. Perlu dilakukan pengelolaan database peraturan perundang-undangan Di Kanwil Kemenkumham secara profesional yang didukung oleh kuantitas dan kualitas SDM yang memiliki kompetensi di bidang Informasi dan Teknologi melalui kegiatan Pelatihan dan Bimtek, dukungan anggaran dan sarana prasarana yang memadai.

7. Kanwil Kemenkumham harus secara proaktif mencari produk hukum daerah untuk diinput kedalam database Jaringan Data dan Informasi Hukum dan tidak hanya menunggu dari Pemerintah Daerah. 


\section{DAFTAR PUSTAKA}

\section{Buku}

Anwar Yesmil dan Adang, Pengantar Sosiologi Hukum, Grasindo, Jakarta, 2015.

Badan Litbang Kementerian Dalam Negeri., Metode Penelitian Sosial (Terapan dan Kebijaksanaan)., Jakarta: 2000.

Daryanto, Kamus Indonesia Lengkap,Apollo, Surabaya, 1997.

Erni Tisnawati Sule, Kurniwan Saefullah, Pengantar Manajemen, Kencana Perdana Media Group, Jakarta, 2009.

M. Friedman Lawrence, American Law an Introduction (Penerjemah: Wishnu Basuki) , Tatanusa, Jakarta, 2001.

Manulang, Dasar-dasar Manajemen, Ghalia Indonesia, Jakarta, 1990.

Mohammad Aslam Sumhudi., Komposisi Riset Disain., Jakarta: Lembaga Penelitian Universitas Trisakti., 1985.

Panduan Praktis Memahami Perancangan Peraturan Daerah., Jakarta: Direktorat Jenderal Peraturan Perundangundangan., 2011.

Satjipto Rahardjo., Hukum dan Masyarakat., Bandung: Angkasa., 1980.

Suharsimi Arikunta, Pengelolaan Kelas dan Siswa, Rajawali, Jakarta, 1988.

Taliziduhu Ndraha, Konsep Administrasi dan Administrasi di Indonesia,Bina Aksara, Jakarta, 1989.

Wahyudi Kumorotomo, Etika Administrasi Negara, RajaGrafindo Persada, Jakarta.

\section{Jurnal/Majalah}

Warta BPHN Tahun Ke III Edisi XIX Okt-Des 2016.

\section{Peraturan Perundang-undangan}

Undang-undang Dasar RI 1945

Undang-undang Nomor 17 Tahun 2007 Tentang Rencana Pembangunan Jangka Panjang Nasional

Undang-undang Nomor 12 Tahun 2011 Tentang Pembentukan Peraturan Perundang-undangan

Peraturan Presiden RI Nomor 33 Tahun 2012 Tentang Jaringan Dokumentasi dan Informasi Hukum Nasional (JDIHN)

Peraturan Menteri Hukum dan HAM RI Nomor 29 Tahun 2015 Tentang Organisasi dan Tata Kerja Kementerian Hukum dan HAM

Peraturan Menteri Hukum dan HAM RI Nomor 28 Tahun 2014 Tentang Organisasi dan Tata Kerja Kantor Wilayah Kementerian Hukum dan HAM
Peraturan Menteri Hukum dan HAM RI Nomor 2 Tahun 2013 Tentang Standarisasi Pengelolaan Teknis Dokumentasi dan Informasi Hukum

\section{Website}

http://www.hukumonline.com/berita/baca/lt4d09 89a80b9af/minimnya-idatabaseiperaturanpersulit-harmonisasi-hukum Minimnya Database Peraturan Persulit Harmonisasi Hukum Penyelenggaraan sistem informasi peraturan perundangundangan masih sektoral dan tidak lengkap. (Dilihat Pada Tanggal 5 Januari 2017)

http://www.kemendagri.go.id/media/filemanager /2016/06/21/b/a/batal_perda_21_juni_201 6.pdf (Dilihat Pada Tanggal 6 Januari 2017) 


\section{HALAMAN KOSONG}

